\title{
FDI Volatility and Development
}

Irene van Staveren

\section{Introduction $^{1}$}

It is generally assumed that the volatility of international capital flows predominantly occurs through portfolio investments, and much less through Foreign Direct Investments (FDI). The high volatility in portfolio investments, especially in equity, is particularly stark during financial crises due to its high liquidity as compared to FDI. But this does not necessarily imply that outside crises and over the long run FDI is a stable capital flow. With the enormous growth in financial globalization as well as financialization of the global economy, in which companies worldwide are increasingly driven by strategies to maximize short-term shareholder value across the globe, it is possible that FDI may have become more volatile over time and also increases in volatility during crises. If this would be the case, this would add to the already high uncertainty in investments caused by the sharp volatility of portfolio investments. Moreover, policies to stabilize FDI are less straightforward than those for stabilizing portfolio flows, because FDI flows depend more strongly on non-financial performance criteria of an economy, including political stability, social climate, and labour market conditions. These policies are more complex to design and to enforce, as they will partly go against existing international agreements such as those of the WTO, as Chang (2004) has shown ${ }^{2}$. Hence, if FDI flows would become more volatile over time and if they show increased volatility during crises, this is likely to have a negative impact on macroeconomic stability and, through policy responses of labour market flexibilization, also negative effects on the quality of employment.

The purpose of this chapter is to describe the development in FDI volatility in developing countries over the long run, that is, the period 1970-2008, as well as in relation to crises. In addition, the paper will try to indicate whether, and to what extent, FDI volatility may have an impact on real economy variables. The focus will be on GDP growth, tax revenue and labour market variables. The next section will provide an overview of FDI volatility with descriptive data analysis. The following section will present and discuss some bi-variate regression results with FDI volatility as independent variable. The chapter will end with a conclusion.

\footnotetext{
${ }^{1}$ This chapter was written when I was fellow at the NIAS (Netherlands Institute for Advanced Study in the Humanities and Social Sciences). I greatly acknowledge the opportunity that NIAS has given me for reflection and inspiration.

${ }^{2}$ Chang (2004) mentions, among others, limiting ownership, limiting technology transfer, preferential local procurement, and barriers to 'brownfield' investments.
} 


\section{FDI Volatility in the Literature}

The empirical literature on FDI volatility is quite limited, as compared to the body of research on FDI volumes. A common result from the literature on FDI volumes (stocks and flows) is that there is a positive effect on GDP growth for developed as well as for developing countries, and hence, FDI moves pro-cyclically (World Bank, 1999). Although there are exceptions, as for example Rajan (2008) demonstrates for developing countries over the long run, and is argued in a study with long run panel data and time series by Sarkar (2004). Sarkar shows that only in a very small group of relatively rich open economies the relationship between FDI and growth is positive, whereas for the majority of developing countries, no relationship could be established. There are very few studies that look at other impacts than those of FDI volumes on GDP growth, with an interesting exception of a study finding a negative impact of FDI inflow on child labour (Davies and Voy, 2009) and another study finding that for middle income developing countries there is a negative relationship between FDI inflow and gender disparity in education (Busse and Nunnenkamp, 2009). Other studies point at low quality of FDI, for example in terms of environmental impact, skill and technology transfer, and employment (see, for example, on Latin America: Gallagher and Chudnovsky, 2009).

When turning to the scarce empirical literature on FDI volatility, we find that the empirical results of regression analyses of FDI volatility on GDP growth tend to show a negative impact (Choong and Liew, 2009; Lensink and Morrissey, 2001). The literature is, however, rather silent on the possible mechanisms that would help to explain this negative impact. Because volatility tends to increase uncertainty, the explanations of negative impacts on growth and other variables generally refer to Keynesian mechanisms: a general lowering of investment due to lower expected returns in times of higher volatility (a mechanism that may run both ways: from unstable growth to volatile FDI and the other way around), and insufficient macroeconomic stabilization mechanisms in developing country economies to dampen FDI volatility (a policy argument). There are three likely mechanisms that may explain a negative impact of FDI volatility on receiving economies. First, the domestic business sector may hold up investment due to uncertainty about foreign technology or matching capital coming in. Second, workers are likely to experience more job insecurity due to "a growing demand for more flexible hiring-and-firing practices as a buffer against large and unexpected swings in the overall level of economic activity" (DESA, 2008: 34) which links to FDI because in developing countries FDI inflows often go to labour-intensive industries. Moreover, as the ILO has shown, the bargaining power of labour vis-à-vis foreign capital has declined with globalization (ILO, 2008). The job insecurity may lead to lower consumer expenditures as a reaction to more insecure livelihoods at the household level. Third, the government may not have sufficient automatic stabilizers in place through the tax system, subsidies, and the substitution of private sector investment by public investment through borrowing on domestic capital markets. The first and third mechanism both imply a crowding out of domestic investment with higher volatility of FDI inflows, a hypothesis that has been discussed, but not adequately tested, by Agosin (2008).

Explanations of increasing FDI volatility also refer to institutions, arguing that there is a relationship between FDI inflow and institutional strength of countries. This explanation can be divided up into the strength of national institutions and the participation in international institutions. Countries with weak economic, social and political institutions attract relatively less portfolio investment and more direct 
investment, so that FDI tends to flow relatively more to less stable economies (Hausman and FernándezArias, 2000). Alternatively, countries which participate in global economic institutions of trade and investment, in particular WTO, tend to experience less FDI volatility (Büthe and Milner, 2008). Hence, stronger domestic institutions or participation in international institutions would likely decrease FDI volatility because of the stability that these institutions provide for investment. At the micro level, FDI instability may actually mirror a quick outflow of equity capital through short term financial transactions between subsidiaries of a multinational firm, as Loungani and Razin (2001) have suggested ${ }^{3}$. This means that financialization at a global scale through multinational corporations' global financial management strategies could make FDI flows more similar to portfolio movements: quicker FDI in and outflows and hence higher levels of volatility.

The FDI data used in this chapter is from UNCTAD's online world investment database. It uses FDI inflows as a ratio over GDP. The database's latest available data at the time of writing was for 2008, but a study by UNCTAD itself of the preliminary data over 2009 indicates that global FDI flows have gone down by $39 \%$ globally and $35 \%$ in the developing world (UNCTAD, 2010) ${ }^{4}$. This is likely to increase the volatility measure over the last period, if 2009 data would be included.

On the measurement of FDI volatility, there are two methods that are commonly used. The first method is a statistical measure, the standard deviation of FDI inflows over a certain period of time. Since the measure of FDI is taken as a ratio over GDP, there will not be a bias in the measure stemming from the huge differences in actual amounts of FDI inflows between countries due to differences in the size of their economies. Since FDI (and GDP) increases over time, the statistical measure can be further refined by normalizing it, through dividing the standard deviation by the mean per period. For the disaggregation of FDI into greenfield investment and mergers and acquisitions, the volatility measure is weighted by the mean, since the FDI data are expressed in US dollar. The second measure that is common in the literature is a theoretical measure, since it measures deviations from the trend of FDI inflows per country. It is calculated as the standard deviation of the residual through auto-regressions and generates an indicator of investors reactions to the market trend. In this chapter I will use the statistical measure for two reasons. First, as others have pointed out as well, the difference with the auto-regression measure tends to be very small. Second, it is a purely macroeconomic descriptive measure, rather than reflecting a theoretical financial market perspective assuming a trend line of foreign investors actual annual increases in investment. A final note on measurement is that it should be kept in mind that FDI is not entirely independent from GDP. FDI may increase investment and hence production (and often also exports), stimulating GDP. But FDI may also lead to increased imports, both of the capital goods invested and of raw materials or intermediate products, which has a downward affect on GDP.

\section{Descriptive Data Analysis}

\footnotetext{
3 "For instance, the foreign subsidiary can borrow against its collateral domestically and then lend the money back to the parent company. Likewise, because a significant portion of FDI is intercompany debt, the parent company can quickly recall it." (Loungani and Razin, 2001: 5).

${ }^{4}$ For individual countries, UNCTAD estimates the decline in FDI inflow between only $3 \%$ for China up to $66 \%$ for Malaysia.
} 
The data set includes 121 developing countries, from which Oceania and a few other small island economies were excluded because they appeared to be outliers and tend to experience more volatility over the whole study period due to their deliberately sought status as investment paradises ${ }^{5}$. The descriptive data analysis covers the period 1970-2008, which has been divided up in 5 year periods (except for the last period due to unavailable data for the year 2009).

Before turning to the volatility of FDI, I will first show the trend in FDI inflows to developing countries in diagram 1. The figure clearly shows an increase of FDI inflow, as a percentage of GDP, over the period. The line also suggests an increase in volatility with decreases during periods of (local) crises. Surprisingly, the current global financial crisis seems already reflected in the data for the year 2008, with a modest decline of FDI inflow from 7.32 to 7.06 percent of GDP. One would have expected, since the crisis originated in the developed world and is concentrated in the US and European economies, that the impact on FDI in developing countries would not be noticeable, at least not immediately. The figures however suggest that there was a quick reaction in US and EU firms' international investment decisions, most likely because of an urgent need for liquidity by the parent companies, which may have led to either a reduction of new FDI or the use of existing subsidiaries to refund parent companies (see also footnote 2).

Diagram 1. FDI inflow to developing countries $(\mathrm{n}=121)$ 1970-2008

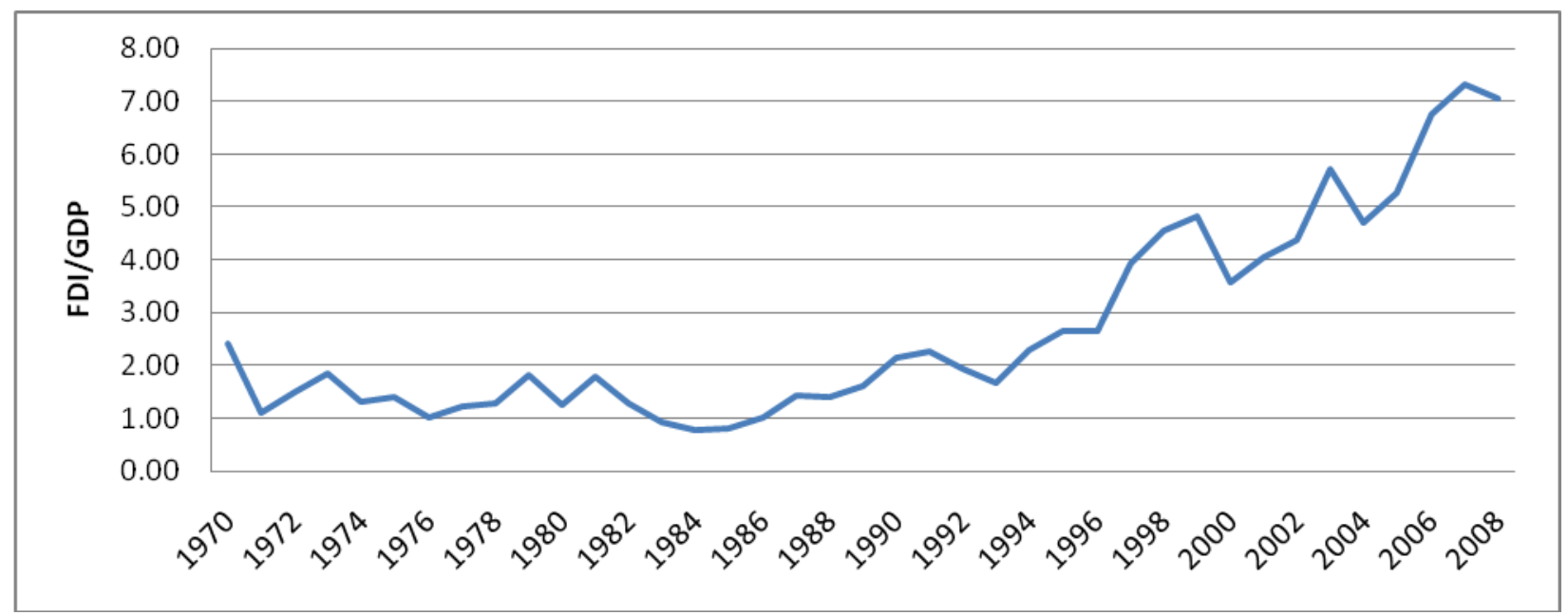

Diagram 2 shows a regional breakdown of the FDI inflow to the developing world. The diagram reflects the higher inflow of FDI/GDP in Latin America over almost the whole period, followed by Africa and then Asia. The reason why Africa scores higher than Asia, except for the early 1990s, is probably, as was

\footnotetext{
${ }^{5}$ For example, the standard deviation of FDI/GDP for the Cayman Islands appeared to be over five times of that of the country with the next highest score.
} 
indicated in the literature review, because African economies tend to be weaker than Asian economies, and hence, they attract relatively less portfolio investments and more FDI.

\section{Diagram 2. FDI inflow in three regions, 1970-2008}

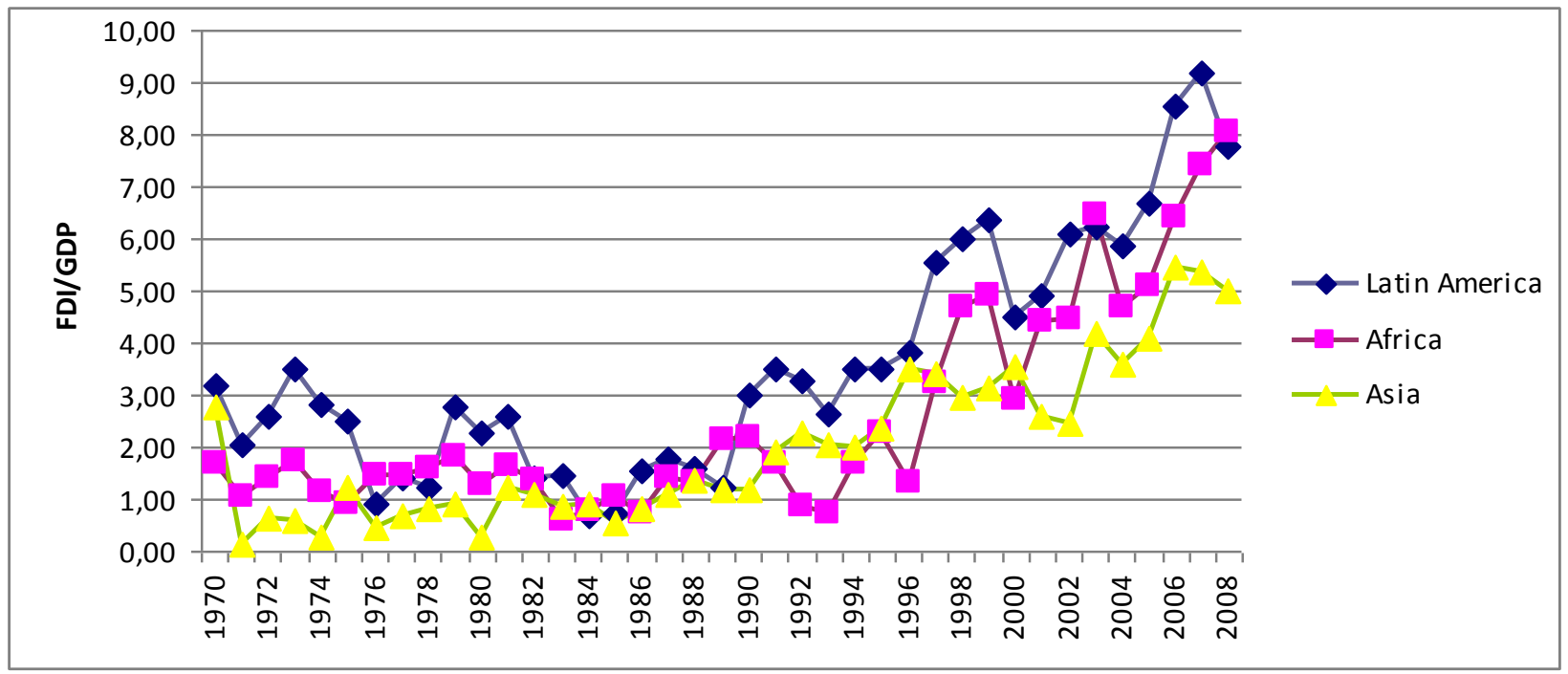

We now turn to the volatility of FDI inflows. Diagram 3a shows the development of volatility of FDI inflows in the developing world measured as the standard deviation of FDI as a percentage of GDP over five year periods, between 1970 and 2008. Diagram 3b shows the standardized measure of volatility, namely the standard deviation divided by the mean per period, which corrects for the increase in FDI/GDP over time, a trend which was shown in diagram 1. Diagram 3a shows that, although volatility decreased until the early 1980s, it increased since then with a stabilization in the first decade of the new millennium at higher levels than before, with standard deviations of FDI over GDP of around 2.65 since 1995. The last bar includes, as we have seen from the diagrams above, the decline of FDI inflows over 2008, which, as mentioned earlier, will further decline significantly in 2009, according to UNCTAD (2010), probably leading to a further increase of the volatility measure for the last period. The standardized measure shown in diagram $3 b$, however, shows that with increasing volumes of FDI and shares of FDI in GDP, standardized volatility tends to go down, although it still features periods of increased volatility, in the early 1990s and in the most recent period, since 2005 . The standardized measure suggests that there is no reason to worry about FDI volatility over time, because increased inflows do not seem to lead to higher volatility. But this does not mean that the increased volatility as experienced by countries, the one expressed in diagram 3a, has no disturbing impact on their economies. 
To the contrary, it may well be that the experience of higher uncertainty about the expected level of inflow of foreign investment may have effects on domestic investment, import and exports, production, labour markets, and government revenues, and, through these variables, on economic growth. But we first need to get a better understanding of the volatility itself.

Diagram 3a. Volatility of FDI inflow in developing countries $(n=121), 1970-2008$

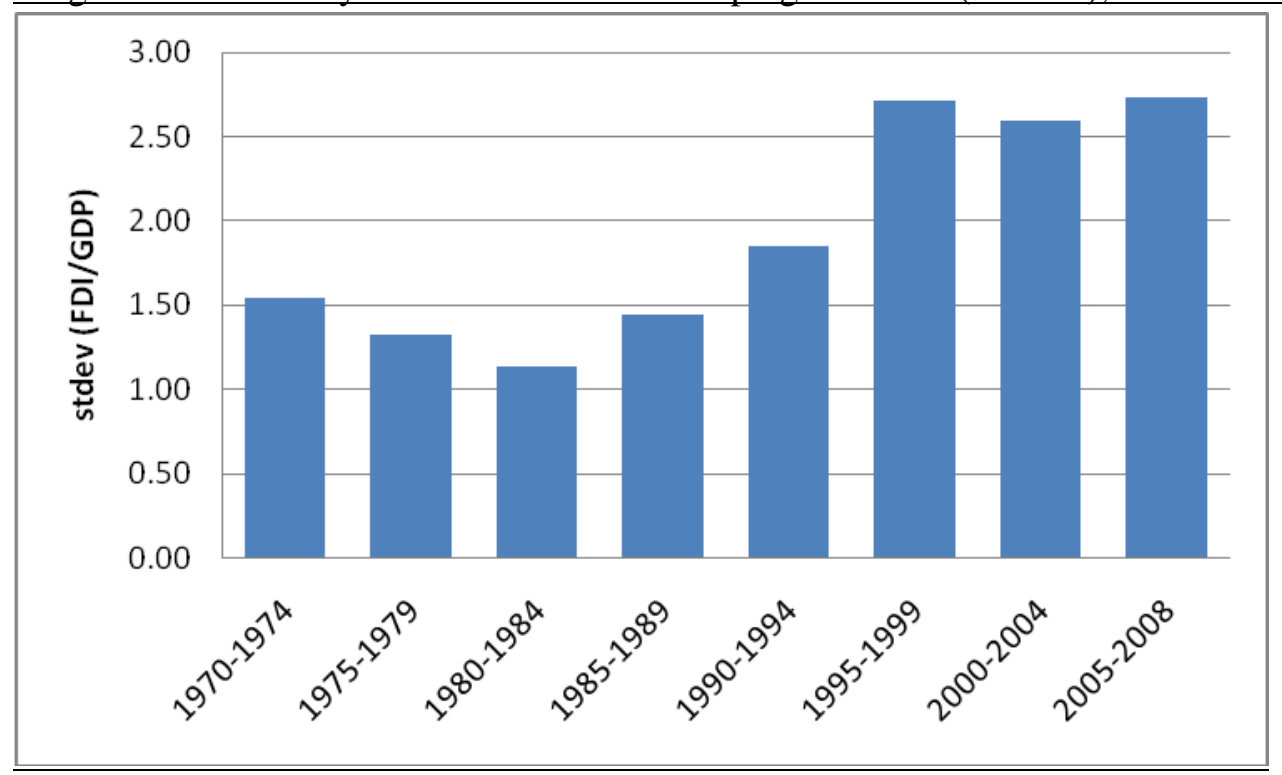

Diagram 3b. Standardized volatility of FDI inflow in developing countries ( $\mathrm{n}=121), 1970-2008$ 


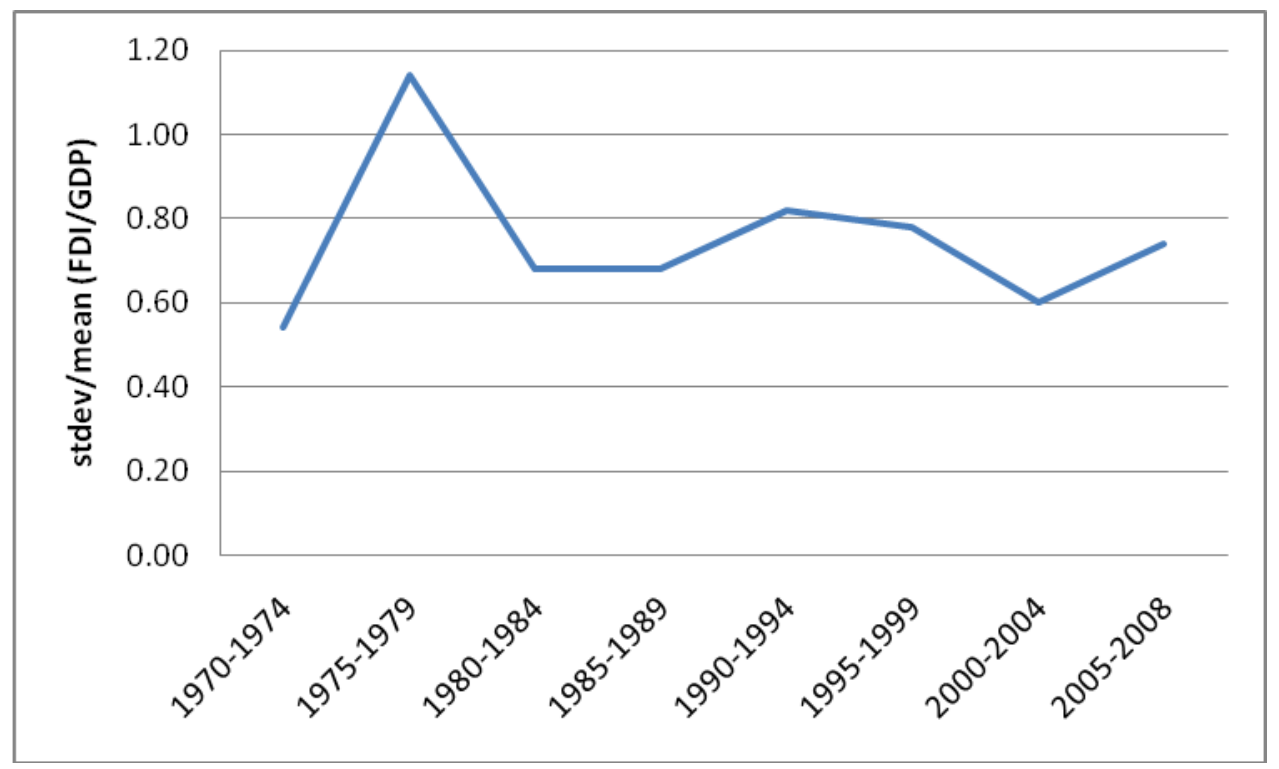

The analysis in this paper is concerned with FDI volatility because it is expected that the current global financial crisis not only hurts portfolio investments such as equity, real estate, currency speculation and pension funds, but also longer term investment. As we have seen above, the most recent UNCTAD data on FDI inflows confirm this fear. But it is also insightful to look at previous financial crises that were more localized into a region or a single country. In table 1 below, I compare the volatility of FDI inflows for four financial crises in the recent past with volatility for the whole data period. I include three years before the crisis, when in all countries investment inflows were building up, and four years after the crisis, the period when GDP and other important indicators generally tend to go back to the level experienced before the crisis and when investment inflows have more or less recovered from the shock. The comparison shows that for seven out of the eight countries concerned, the level of volatility during the 8year crisis period was higher than for the whole period of 39 years. The exception is Korea which shows a rather stable FDI inflow even during the Asian financial crisis when its portfolio inflows turned into net outflows.

Table 1. Comparison of volatility (stdev FDI/GDP) during crisis periods with the whole data period.

\begin{tabular}{|c|r|r|}
\hline Country (crisis year) & 1970-2008 & $\begin{array}{l}\text { Crisis period } \\
\text { (8 years, crisis } \\
\text { year t = 4) }\end{array}$ \\
\hline Thailand (1997) & 1,66 & 2,07 \\
\hline Korea (1997) & 0,82 & 0,77 \\
\hline Malaysia (1997) & 1,92 & 2,05 \\
\hline
\end{tabular}




\begin{tabular}{|c|r|r|}
\hline Indonesia (1997) & 1,29 & 1,97 \\
\hline Philippines (1997) & 0,83 & 0,84 \\
\hline Argentina (2002) & 1,54 & 2,17 \\
\hline Brazil (1999) & 1,27 & 1,40 \\
\hline Turkey (2002) & 1,18 & 1,62 \\
\hline
\end{tabular}

In order to get an idea of the volatility in the last four years leading up to the current global financial crisis, the next diagram gives a breakdown of the FDI inflows (FDI/GDP) for the last period for each region. Diagram 4 shows no disturbance from the trend for Africa but a steadily increasing trend, suggesting that FDI to Africa is not (yet) affected by the crisis. In Latin America the decline starts in 2008, whereas in Asia the decline already begins in 2007. More detailed analysis per region, in terms of type of FDI inflow, countries of origin, and economic sector may help to explain the regional differences. Diagram 5 below shows the volatility of FDI inflows per region for the whole period, which is a breakdown of diagram $3 \mathrm{a}$.

Diagram 4. FDI inflow per region for the period 2005-2008

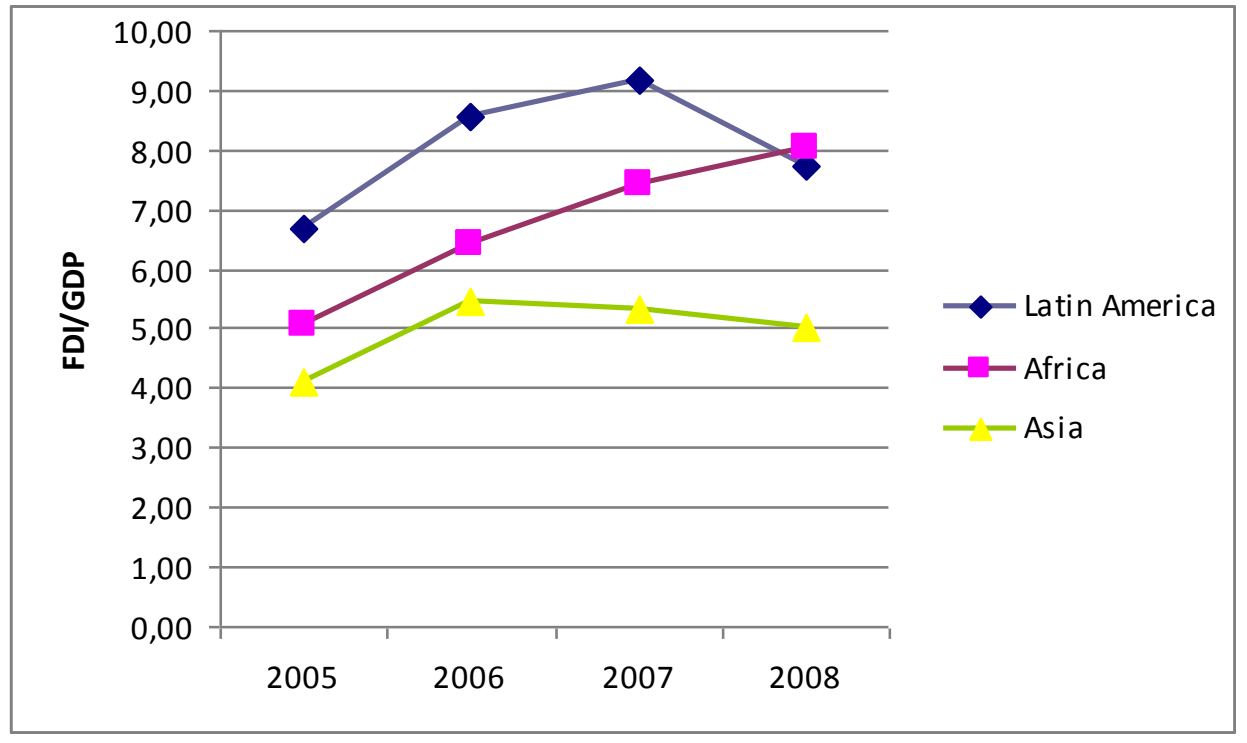

Diagram5 clearly shows that volatility in FDI inflows went up in all three regions since the 1980s, with the steepest increase in Africa. The last period shows an increase for Latin America and Africa, but a 
decline in volatility for Asia. To what extent the current financial crisis and/or lessons learned in Asia from the 1997 financial crisis may be responsible for this divergence can only be understood with a detailed regional analysis of trends and policies.

Diagram 5. Volatility of FDI inflow per region, 1970-2008

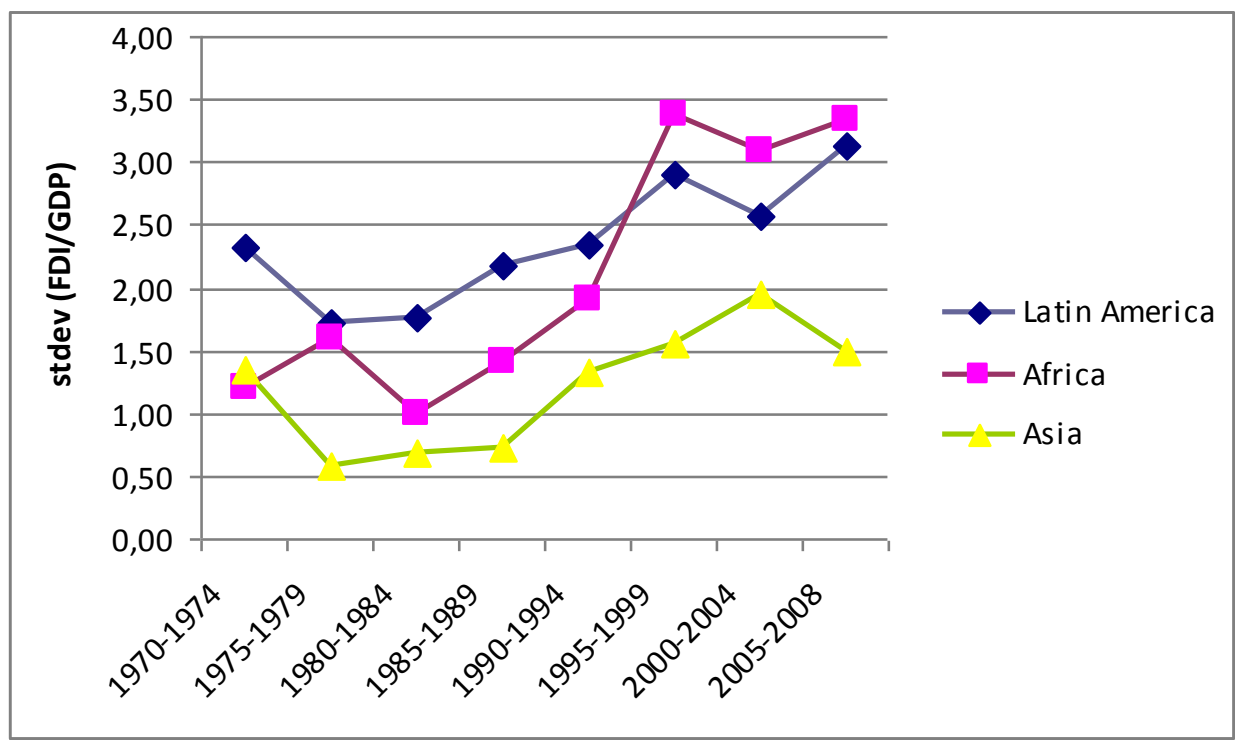

As a summary, table 2 below provides an overview of the volatility indicators for all developing countries together as well as per region.

Table 2. Volatility of FDI inflows (stdev FDI/GDP), 1970-2008

\begin{tabular}{|l|c|c|c|c|c|c|c|c|}
\hline Period: & $\begin{array}{c}\mathbf{1 9 7 0 -} \\
\mathbf{1 9 7 4}\end{array}$ & $\begin{array}{c}\mathbf{1 9 7 5 -} \\
\mathbf{1 9 7 9}\end{array}$ & $\begin{array}{c}\mathbf{1 9 8 0 -} \\
\mathbf{1 9 8 4}\end{array}$ & $\begin{array}{c}\mathbf{1 9 8 5 -} \\
\mathbf{1 9 8 9}\end{array}$ & $\begin{array}{c}\mathbf{1 9 9 0 -} \\
\mathbf{1 9 9 4}\end{array}$ & $\begin{array}{c}\mathbf{1 9 9 5 -} \\
\mathbf{1 9 9 9}\end{array}$ & $\begin{array}{c}\mathbf{2 0 0 0 -} \\
\mathbf{2 0 0 4}\end{array}$ & $\begin{array}{c}\mathbf{2 0 0 5 -} \\
\mathbf{2 0 0 8}\end{array}$ \\
\hline Latin America & 2.31 & 1.72 & 1.76 & 2.17 & 2.33 & 2.90 & 2.56 & 3.12 \\
\hline Africa & 1.20 & 1.59 & 0.99 & 1.42 & 1.90 & 3.37 & 3.09 & 3.33 \\
\hline Asia & 1.35 & 0.58 & 0.68 & 0.74 & 1.32 & 1.56 & 1.95 & 1.49 \\
\hline All developing countries & 1.55 & 1.33 & 1.13 & 1.45 & 1.85 & 2.71 & 2.60 & 2.73 \\
\hline $\begin{array}{l}\text { All developing countries } \\
\text { standardized }\end{array}$ & 0.54 & 1.14 & 0.68 & 0.68 & 0.82 & 0.78 & 0.60 & 0.74 \\
\hline
\end{tabular}

FDI inflows can be distinguished between greenfield investments and mergers and acquisitions (M\&A) ${ }^{6}$. Diagram 6 below shows the breakdown of FDI in M\&A and greenfield investments per year between

\footnotetext{
${ }^{6}$ Note that the data includes negative numbers for greenfield investments, representing disinvestments, but not for mergers and acquisitions.
} 
1987 and 2005, the period for which disaggregated data was available. The figure shows that on average greenfield makes up a larger share of FDI over the whole period. The average shares are $65 \%$ for greenfield and 35\% for M\&A investment ${ }^{7}$. Diagram 7 shows the development of the two types of FDI relative to GDP. Greenfield investment clearly makes up a larger part of GDP than mergers and acquisitions. There also seems to be a difference in reaction to financial crises. For the Asian financial crisis of 1997, the figure shows only a small decline of M\&A but a steep, though shorter, fall in greenfield investment. Also, the dotcom crisis of 2000 seems to have affected greenfield investment more than M\&A. But in the more recent years, the figure shows more volatility in M\&A compared to greenfield investment, a change which cannot be linked to global financial crises. This seems to suggest that in times of financial crises, greenfield investments are more vulnerable than M\&A, perhaps because it is easier to disinvest in $100 \%$ owned self-initiated production facilities as compared to disinvestments in take-overs, joint ventures and minority participations in local firms. But this is a hypothesis which needs more detailed research beyond what is possible with the data that were available for this study.

Diagram 6. Shares of M\&A and greenfield investment in FDI ( $\mathrm{n}=117), 1987-2005$

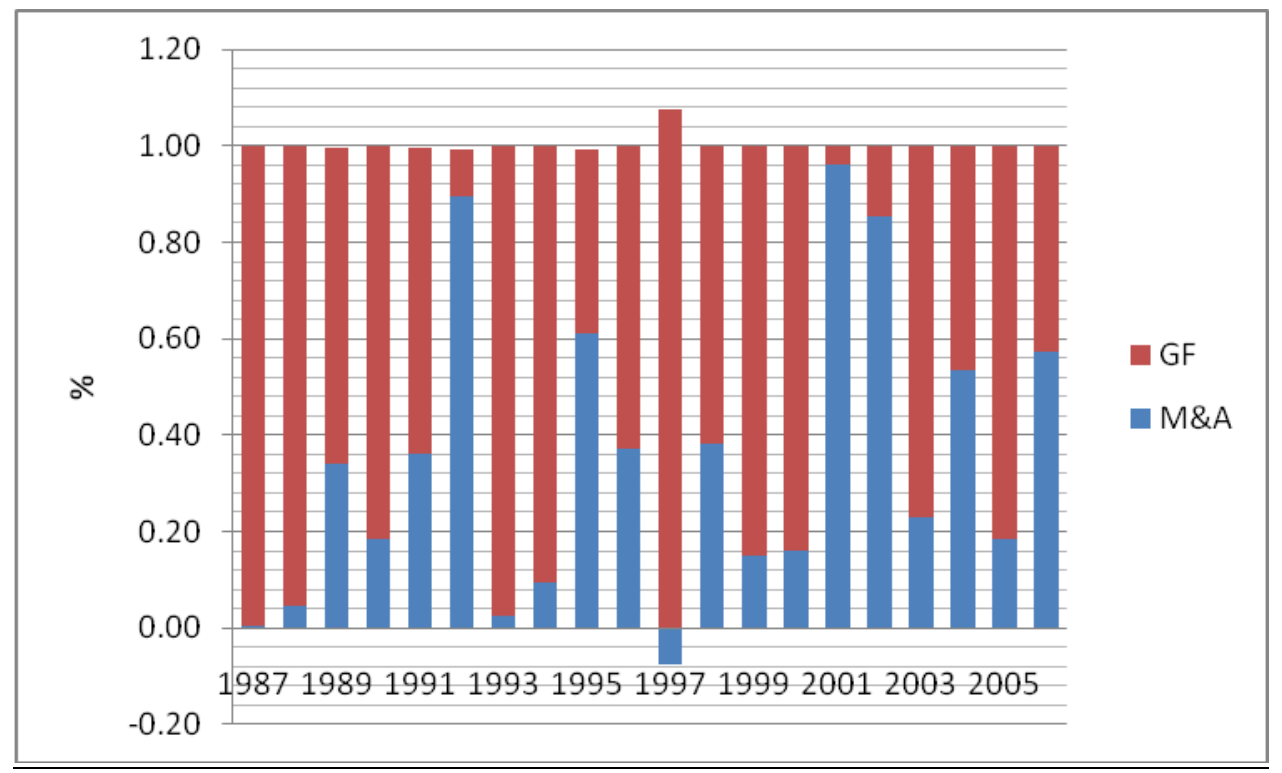

\footnotetext{
${ }^{7}$ These averages exclude three outliers (Bahamas, Cuba and South Africa). The averages including these three outliers are $160 \%$ M\&A and $-60 \%$ greenfield as shares in FDI.
} 
Note: three outliers were excluded: Bahamas, Cuba and South Africa.

Diagram 7. Share of M\&A and greenfield investment in GDP $(\mathrm{n}=117), 1987-2006$

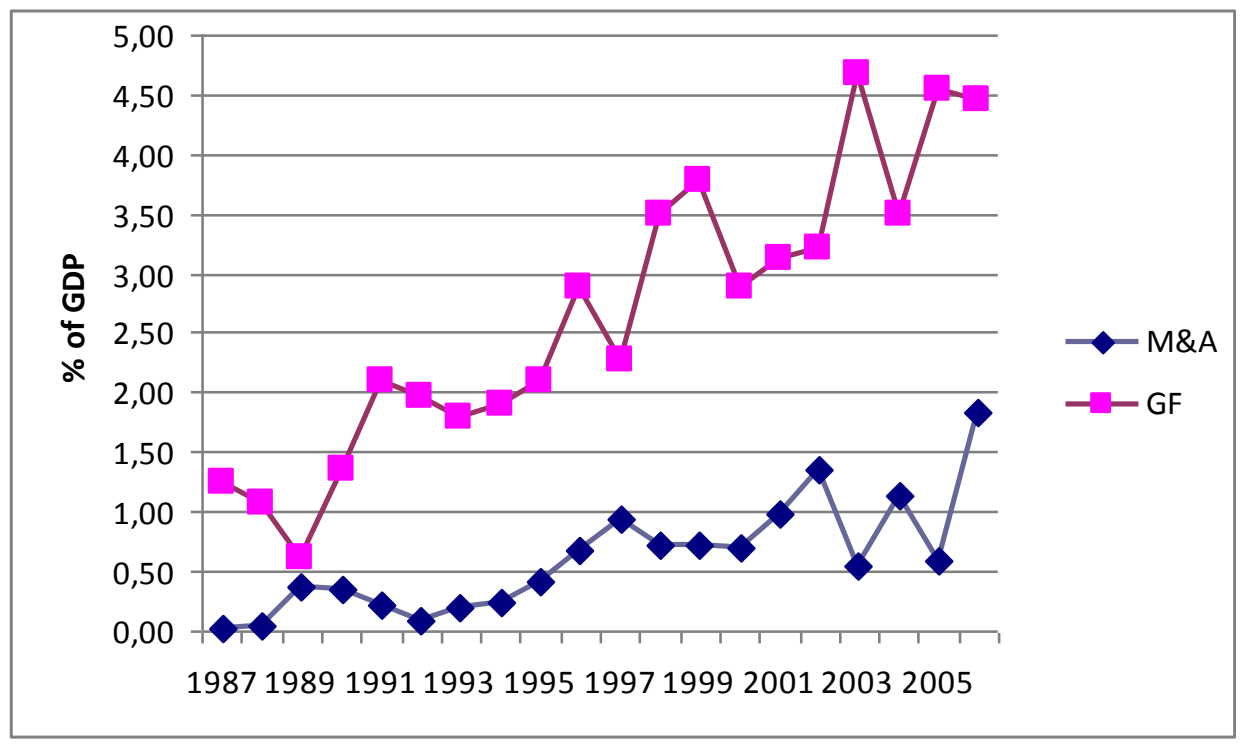

Note: three outliers were excluded: Bahamas, Cuba and South Africa.

The database used in this study does allow for an analysis of volatility in the two types of FDI. Diagram 8 shows the development of volatility in the two types of FDI for all developing countries, for the period 1987-2006, the period for which disaggregated data is available ${ }^{8}$. The figure shows that when we break down FDI, the volatility level of M\&A is higher than that of greenfield investment but both have declined over time. This means that with increasing levels of both types of FDI, absolutely as well as relative to GDP as was shown in diagram 7, volatility has not increased simultaneously. The decrease, however, does not continue: in the last period it stabilizes for greenfield investment whereas it increases for M\&A.

Diagram 8. Volatility in greenfield and M\&A $(n=120)$

\footnotetext{
${ }^{8}$ Since this is a shorter period as for the overall FDI data, different periods have been made in order to evenly distribute the 20 years of observations.
} 


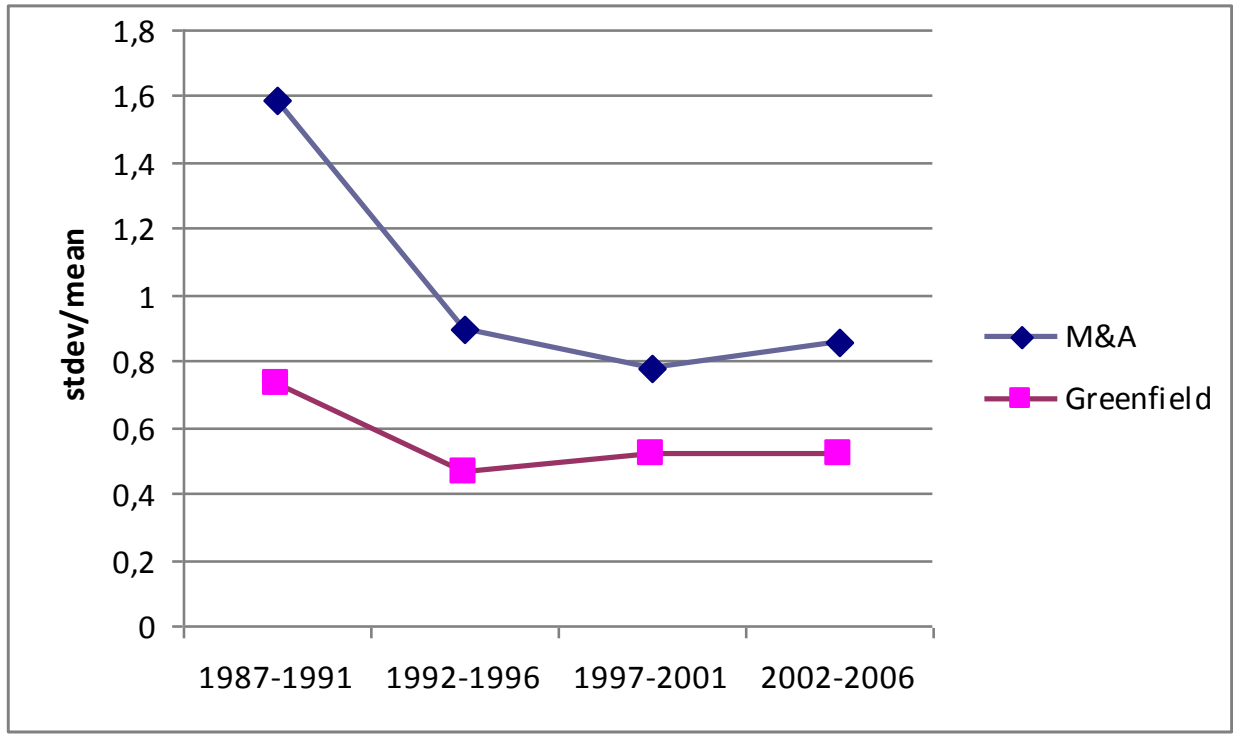

Diagram 9. Volatility in M\&A per region 


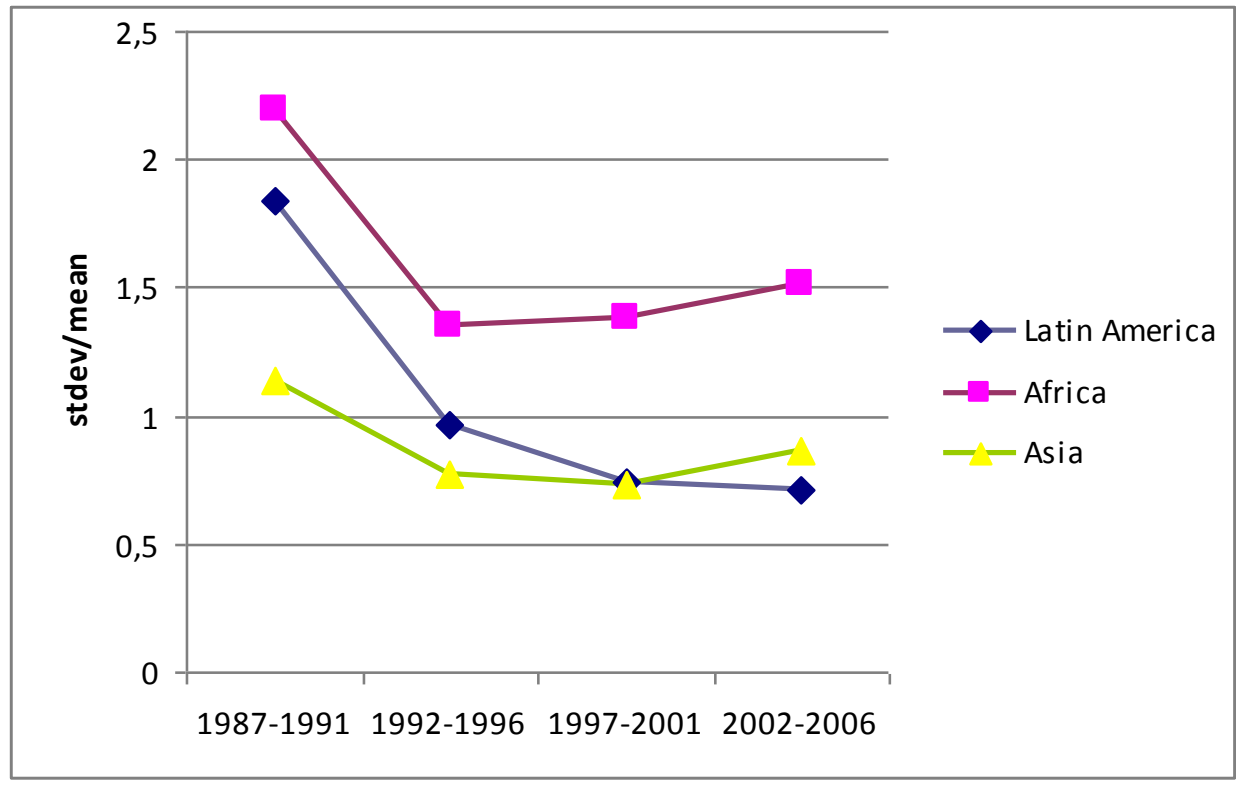

Diagram 10. Volatility in greenfield investment per region

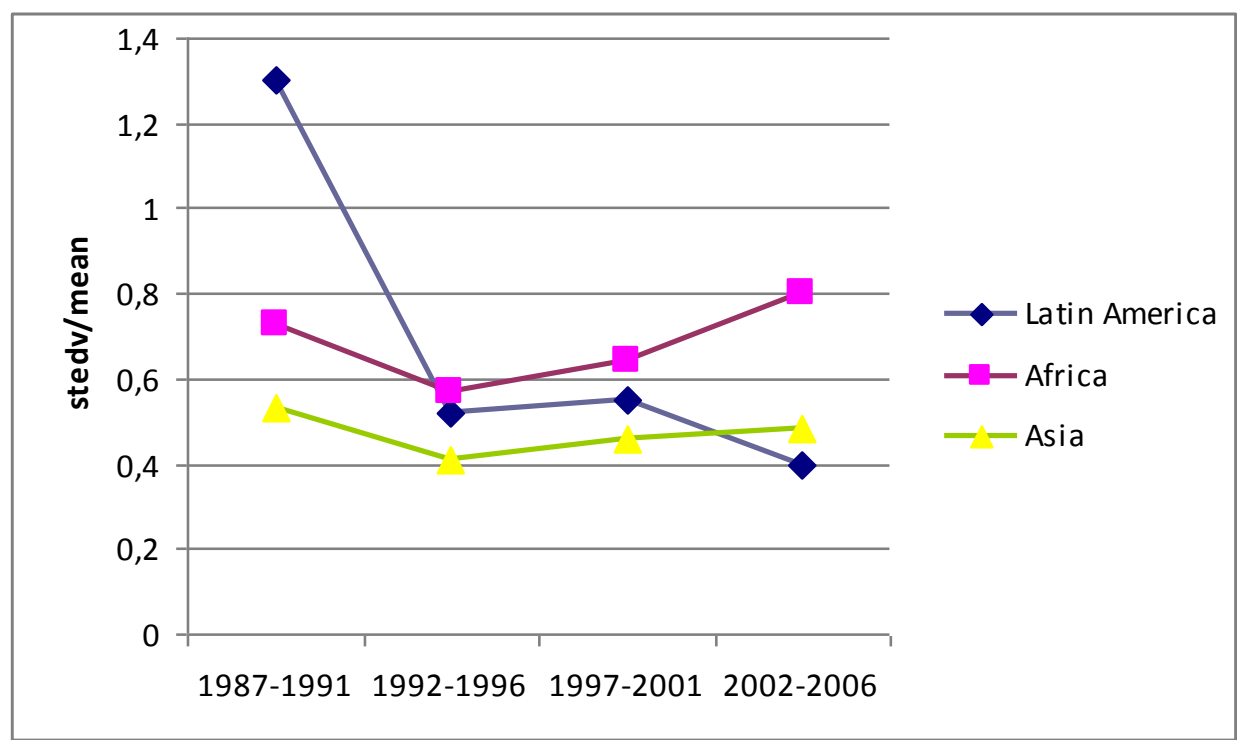

Diagram 9, zooming in on mergers and acquisitions, shows that the volatility in M\&A is U-shaped for Africa and Asia, whereas it flattens out for Latin America. The figure suggests that volatility declined in the 1990s but raised again after the 1997 Asian financial crisis in Africa and Asia. The increase in Asia may be a side effect of the capital controls taken by various Asian countries after the crisis, in order to stabilize portfolio investment flows: this may have led to some substitution of investment from portfolio 
to mergers and acquisitions. Such substitutions may have also included some of the volatility that is inherent in portfolio investment, for example through accounting transactions between a corporation and the companies in which shares have been acquired (note that the data includes all M\&A transactions with at least $10 \%$ of shares, hence, the data includes up to $100 \%$ acquisitions). Finally, diagram 10 shows a similar pattern of volatility for each region for greenfield investment, but now with Latin America decreasing also in the last period. There is an increase in volatility in greenfield investments in all three regions in the period of the Asian financial crisis.

In order to get a more detailed picture of the different reactions of M\&A and greenfield investment during financial crises, table 3 below compares the volatility measures for the two types of FDI for the eight countries discussed earlier during crises periods. The data indicate that whereas for six countries the differences between $M \& A$ and greenfield are small and not pointing in any direction, for two countries, Indonesia and the Philippines, the volatility in greenfield investment is much higher.

Table 3. Comparison of volatility in two types of FDI during financial crises periods

\begin{tabular}{|c|r|r|}
\hline Country & $\begin{array}{l}\text { M\&A volatility } \\
\text { (stdev/mean) }\end{array}$ & $\begin{array}{l}\text { Greenfield } \\
\text { volatility } \\
\text { (stdev/mean) }\end{array}$ \\
\hline Thailand & 0,98 & 0,51 \\
\hline Korea & 1,12 & 0,74 \\
\hline Malaysia & 0,65 & 0,69 \\
\hline Indonesia & 1,05 & 262,76 \\
\hline Philippines & 0,78 & $-9,95$ \\
\hline Argentina & 1,23 & 1,47 \\
\hline Brazil & 0,73 & 0,72 \\
\hline Turkey & 1,69 & 1,86 \\
\hline Average & 1,03 & 32,35 \\
\hline
\end{tabular}

Note: as in table 2 , the periods include 8 years with the crisis year $\mathrm{t}=4$.

The volatility diagrams and table above suggest that over the long run M\&A is the more volatile form of FDI, whereas during financial crisis, greenfield shows more volatility on average. This would point at a dilemma for developing countries who want to stabilize their foreign capital inflows by specializing on either M\&A or greenfield investment: there may be a trade-off between long run stability and short run 
stability. In other words, specializing in greenfield may reduce long run volatility whereas specializing in M\&A is more likely to reduce volatility in crisis periods.

\section{Bi-variate Regression Analysis}

With increasing FDI volatility, paralleling higher inflows of FDI, both absolutely as well as relative to GDP, it may well be that the real economy is directly or indirectly affected by the higher levels of volatility. As was briefly discussed in the introduction, possible effects are likely to run through GDP growth, tax revenues, and labour market flexbilization. These possible impacts, however, will also be influenced by other trends (such as globalization with its accompanying weakening of trade unions vis-àvis mobile capital) and by various policy variables as a reaction to FDI volatility (such as investment subsidies, tax competition, and labour market deregulation). Therefore, the regression analysis in this section will only include bi-variate regressions, in order to give an indication of possible impacts of FDI on the real economy, recognizing that other factors play a role as well, and that there are likely indirect effects that may either weaken the correlations, as dampening effects, or that could increase the found correlation coefficients due to positive feedback effects. The results presented in this section should therefore be taken with caution, and are only indicative of possible impacts of FDI volatility on the real economy in developing countries.

Table 4 below provides an overview of some bi-variate regression results with FDI volatility as the independent variable and, to compare, FDI inflow, as well as volatility in the two types of FDI. This allows us to compare correlations between volatility and possible impact variables with correlations of flows with the same variables. Such a comparison will give an indication whether the possible impacts would be similar or different for flows and volatility of FDI. For the dependent variables, the regression analysis includes GDP growth, tax revenue and the vulnerable employment rate for men and women. The data combines cross-section data and time-series data, leading to three periods of observations per country: 1990-1994; 1995-1999; 2000-2004. These periods were chosen as they are the most volatile periods for FDI inflows, moreover, there was insufficient data available for earlier periods and for the last period.

The table shows quite similar results for the two aggregate independent variables in terms of signs and statistical significance. This is probably due to the fact that over the period both variables went up: FDI inflows as well as FDI volatility. Indeed, the Pearson correlation between the two variables is quite high, $0.68(\mathrm{p}<0.01, \mathrm{n}=90)$. What is striking about the dependent variable GDP growth is that the sign is unexpected: whereas the macroeconomic literature finds a negative correlation between FDI volatility and GDP growth, these results show a positive and statistically significant correlation. This would suggest that not only the increase in FDI inflows is beneficial for GDP growth but even its volatility may have a positive impact on growth. It is difficult to find a theoretical explanation for this result, which should probably be attributed to the particular time period involved and the lack of control variables ${ }^{9}$. One explanation may be related to a policy response to higher uncertainty about foreign investments, namely

\footnotetext{
${ }^{9}$ When, in an alternative regression, both FDI inflow and FDI volatility as well as their interaction term are included, the sign for the volatility variable becomes negative. But in that exercise, only the parameter for the interaction term is statistically significant.
} 
an overreaction in policies to attract a steady inflow of FDI. Relevant policy variables would be tax breaks, investment subsidies, and labour market deregulation, as well as complementary government investment in business parks and export processing zones. Some of these policy measures are likely to create positive externalities for domestic investment and capacity utilization in existing production facilities, which have in turn a positive impact on GDP.

The regressions with tax revenue as the dependent variable show no correlation at all and no statistical significant results. The labour market variable for flexibilization, the employment vulnerability rate for males and females, tends to confirm the hypothesis that FDI volatility goes hand in hand with labour market flexibilization. This is in line with studies finding more vulnerable employment with globalization, in both developed and developing countries (as for example reported in ILO, 2008). Obviously, these bi-variate regressions cannot distinguish between labour market flexibilization as a trend (for example through a substitution of fixed contracts into flexible contracts) and flexibilization as a consequence of deregulation policies (for example relaxing minimum wages and labour standards).

The regressions for the two types of FDI suggest that each type of FDI may have partially different impacts. But since, as we have seen above, the share of M\&A and greenfield investment varies greatly over the years, without a clear trend, the expected impacts of FDI are therefore also likely to vary from year to year. This variability in types of FDI over the years makes it very difficult to evaluate FDI volatility in a cross-section study and for time-series. More detailed analysis for a region or a small number of countries would be necessary in order to better understand the varied possible impacts of FDI inflows on developing countries. The bi-variate regression results presented in table 2 indicate that greenfield investment volatility has no impact at all on GDP growth, a result which is statistically significant, whereas volatility in mergers and acquisitions shows a positive and statistically significant effect on GDP growth. This difference may be a consequence of the fact that volatility in greenfield investment includes disinvestments, leading to sometimes negative net greenfield investments for countries in particular periods. M\&A volatility refers only to ups and downs in positive net investment inflows.

For the correlation with tax revenue, a policy variable, the results are the reverse. Greenfield investment volatility shows a negative statistically significant impact on changes in tax revenue, whereas volatility in mergers and acquisitions shows no statistically significant effect. These differentiated results suggest that mergers and acquisitions may be more beneficial for developing countries in times of increasing volatile investment flows than greenfield investments: M\&A seems to have a positive impact on GDP growth and no disadvantageous effect on tax revenue. Why this would be the case requires microeconomic analysis into the different characteristics of the two types of investment. It may be the case that greenfield investments are largely low value added, labour intensive production facilities in export processing zones, attracted partly by tax breaks offered for such investments. While mergers and acquisitions may involve positive externalities through technology transfer, skill upgrading, and reliance on existing forward and backward linkages in the industries in which foreign investors participate. This, in turn, is more likely to contribute to GDP growth in additional ways than only through the exports of low-value added manufactured goods, while tax breaks are not a major policy instrument to attract foreign capital for mergers and acquisitions. 
Finally, it is surprising to see that the regression results for the labour market flexibilization variable shows no statistically significant effects from the breakdown of FDI volatility into greenfield investment and mergers and acquisitions. It is unclear why this is the case, whereas the aggregate FDI volatility variables, both for the flows and the volatility, shows positive statistically significant effects on labour market flexibility. The results suggest that labour market flexibilization and/or deregulation is related to the increase in FDI inflows and volatility as such, and not to a specific type of FDI, which, as was shown in diagram 6, vary extensively as a share of FDI from year to year.

Table 4. Bi-variate regression results for FDI volatility

\begin{tabular}{|c|c|c|c|c|}
\hline $\begin{array}{l}\text { Dependent } \\
\text { variables -> }\end{array}$ & $\begin{array}{l}\text { GDP growth } \\
\text { (constant } \\
\text { LCU) }\end{array}$ & $\begin{array}{l}\text { Tax revenue } \\
\text { as \% of GDP } \\
\text { change }\end{array}$ & $\begin{array}{l}\text { Female } \\
\text { vulnerable } \\
\text { employment } \\
\text { rate change }\end{array}$ & $\begin{array}{l}\text { Male } \\
\text { vulnerable } \\
\text { employment } \\
\text { rate change }\end{array}$ \\
\hline FDI/GDP & $\begin{array}{l}9.985 * * * \\
\mathrm{R}^{2}=0.26 \\
\mathrm{~N}=338\end{array}$ & $\begin{array}{l}0.304 \\
R^{2}=0.00 \\
N=120\end{array}$ & $\begin{array}{l}2.841 * * \\
\mathrm{R}^{2}=0.09 \\
\mathrm{~N}=56\end{array}$ & $\begin{array}{l}8.490 * * * \\
\mathrm{R}^{2}=0.26 \\
\mathrm{~N}=56\end{array}$ \\
\hline Stdev(FDI/GDP) & $\begin{array}{l}2.837 * * * \\
\mathrm{R}^{2}=0.02 \\
\mathrm{~N}=333\end{array}$ & $\begin{array}{l}0.044 \\
R^{2}=0.00 \\
N=120\end{array}$ & $\begin{array}{l}1.816^{* * * *} \\
\mathrm{R}^{2}=0.12 \\
\mathrm{~N}=56\end{array}$ & $\begin{array}{l}3.983 * * * \\
\mathrm{R}^{2}=0.19 \\
\mathrm{~N}=56\end{array}$ \\
\hline Stdev/mean GF & $\begin{array}{l}0.016 \\
R^{2}=0.00 \\
N=295\end{array}$ & $\begin{array}{l}-4.488 * * * \\
\mathrm{R}^{2}=0.12 \\
\mathrm{~N}=111\end{array}$ & $\begin{array}{l}1.253 \\
{ }^{2} \mathrm{R}=0.04 \\
\mathrm{~N}=55\end{array}$ & $\begin{array}{l}0.543 \\
\mathrm{R}^{2}=0.00 \\
\mathrm{~N}=55\end{array}$ \\
\hline Stdev/mean M\&A & $\begin{array}{l}0.853 * * * \\
\mathrm{R}^{2}=0.02 \\
\mathrm{~N}=292\end{array}$ & $\begin{array}{l}0.272 \\
R^{2}=0.01 \\
N=111\end{array}$ & $\begin{array}{l}-0.095 \\
R^{2}=0.00 \\
N=56\end{array}$ & $\begin{array}{l}-0.487 \\
\mathrm{R}^{2}=0.04 \\
\mathrm{~N}=56\end{array}$ \\
\hline
\end{tabular}

Notes: The table reports unstandardized coefficients; $* \mathrm{p}<0.1 ; * * \mathrm{p}<0.05 ; * * * \mathrm{p}<0.01$. In the dataset, countryperiod observations were removed when for the volatility variables stdev/mean $\geq 20$ since these were outliers. 


\section{Conclusion}

This study has analyzed long run developments of FDI inflows into developing countries, their volatility in general and in relation to crises, and possible impacts of volatility on the real economy. FDI inflows, relative to GDP, have increased sevenfold since 1970 . The standardized volatility of these inflows have come down in the 1980s, but show an increase since 2005 . The unstandardized volatility shows a much shorter period of decline of volatility, with an increase beginning in the 1990s and volatility at higher levels since then, as compared to the 1970s. The pattern is quite similar for Asia, Latin America and Africa. The latest figures indicate that the current global financial crisis has seriously affected FDI inflows, with a drop in 2009 of $35 \%$ in developing countries. A comparison of volatility during earlier localized financial crisis (the Asian financial crisis, and the Brazilian, Argentinian and Turkish financial crisis around the turn of the millennium) with long run volatility for each of the countries involved has indicated that volatility of FDI inflow tends to increase in crisis periods. This indicates that during a financial crisis not only short run capital is volatile but also long run relatively stable investment inflows appear to increase in volatility.

A breakdown of FDI in greenfield investment and mergers and acquisitions is relevant because their shares in FDI vary considerably per country and per year. Over the period 1987-2005 greenfield investment was about twice as high as a percentage of GDP compared to M\&A. The volatility decline in FDI concerns both types of investment and for all three regions, although since 2005 volatility in M\&A is rising again while that for greenfield investment remains stable, so far. The comparison of volatility in the two types of FDI for various financial crises for eight countries has indicated that during crises, Greenfield investment is more volatile. This means that from the perspective of reducing uncertainty of foreign capital inflows over the long run, greenfield investment may be more beneficial for developing countries than M\&A, for two reasons. First, the volatility level of greenfield investment is lower than that for M\&A for the whole period. Second, the volatility in greenfield investment stabilizes in the last period, whereas for M\&A it rises. But if policy makers are more concerned with stabilizing FDI inflows in times of crisis, M\&A investments seem to be the safer bet, in particular because some countries have shown very high volatility in greenfield investments, ten to even over two hundred times the volatility in M\&A in the same period.

The bi-variate regression results should be taken with caution, as they ignore other variables that may explain changes in growth, tax revenue and employment vulnerability. Keeping this in mind, the results suggest that FDI volatility is not detrimental to economic growth, but it does seem to increase the rate of vulnerable employment, both for men and for women. Moreover, greenfield investment seems to have a negative impact on tax revenue, whereas this is not the case for M\&A. In addition, volatility in greenfield investment has no significant impact on growth whereas M\&A volatility seems to have a positive impact on growth. Hence, contrary to the descriptive data analysis, the bi-variate regression analysis seems to suggest that M\&A may be the more beneficial type of FDI for developing countries, since it has no negative impact on tax revenue and a positive impact on GDP growth.

The results from the descriptive and bi-variate regression analysis presented in this chapter do not lead to straightforward policy advise on FDI for developing countries. In general, the increase in FDI inflow and volatility does not seem to harm growth, but they may affect poverty and inequality negatively due to a positive correlation with employment vulnerability. When breaking down FDI in greenfield investment 
and M\&A, developing countries seem to face a trade-off. On the one hand, greenfield investment shows a consistently lower level of volatility than M\&A (about 50\% less), while on the other hand volatility in greenfield investment seems higher during financial crises and appears to be correlated to lower tax revenues in the long run, and does not show the positive correlation with growth as M\&A shows. So, stabilizing FDI inflows comes at a cost: going for more greenfield and less M\&A in the FDI mix would help to stabilize direct capital inflows in the long run, but in order to increase the share of greenfield investment tax holidays and/or tax credits seem to contribute to lower tax revenues while during crisis greenfield investment appears to be more volatile. The tax reduction may in turn, through lower social expenditures, have an additional negative effect on poverty and inequality, adding to the already negative effect of FDI inflow and volatility on employment vulnerability. In conclusion, from a policy perspective it all depends whether a country seeks to stabilize FDI inflows in the long run or during crises and to what extent it is prepared to give up tax revenue and equality, and perhaps some growth, for more long run stability of FDI inflows. Further research is needed in order to provide more insight into this dilemma.

\section{References}

Agosin, Manuel (2008) 'Is Foreign Investment Always Good for Development?', Working Group on Development and Environment in the Americas, Discussion Paper No. 9, April.

Busse, Matthias, and peter Nunnenkamp (2009) 'Gender Disparity in Education and the International Competition for Foreign Direct Investment’, Feminist Economics 15 (3), pp. 61-90.

Büthe, Tim, and helen V. Milner (2008) 'The Volatility of Foreign Direct Investment Flows into Developing Countries: Impact of International and Domestic Institutions', mimeo.

Chang, Ha-Joon (2004) 'Regulation of Foreign Investment in Historical Perspective', The European Journal of Development Research 16 (3), pp. 687-715.

Choong, Chee-keong, and Venus khim-sen Liew (2009) 'Impact of Foreign Direct Investment Volatility on Economic Growth of ASEAN-5 Countries', Economics Bulletin 29 (3), pp. 1838-1850.

Davies, Ronald B. and Annie Voy (2009) 'The Effect of FDI on Child Labor', Journal of Development Economics 88, pp. 59-66.

DESA (2008) Overcoming Economic Insecurity. World Economic and Social Survey 2008. New York; United Nations, Department of Economic and Social Affairs.

Gallagher, Kevin P., and Daniel Chudnovsky (2009) Rethinking Foreign Investment for Sustainable Development. Lessons from Latin America. Anthem Press. 
Hausman, Ricardo, and Eduardo Fernández-Arias (2000) 'Foreign Direct Investment: Good Cholesterol?', Inter-American Development Bank Working Paper No. 417. Washington D.C.

ILO (2008) World of Work Report 2008. Income Inequalities in the Age of Financial Globalization. Geneva.

Lensink, Robert, and Oliver Morrissey (2001) 'Foreign Direct Investment: Flows, Volatility and Growth in Developing Countries', CREDIT Research Paper, University of Nothingham, May.

Loungani, Prakash, and Assaf Razin (2001) 'How beneficial is Foreign Direct Investment for developing Countries?', Finance \& Development 38 (2), June, 6pp. URL:

http://www.imf.org/external/pubs/ft/fandd/2001/06/loungani.htm

Rajan, R. (2008) 'Global Imbalances, or Why are the Poor Financing the Rich?', De Economist 156, pp. 3-24.

Sarkar, Prabirjit (2007) 'Does Foreign Direct Investment Promote Growth? Panel data and Time Series Evidence from Less Developed Countries, 1970-2002', MPRA Paper no. 5167, October 2007. URL: http://mpra.ub.uni-munchen.de/5176/

UNCTAD (2010) 'Global and regional FDI Trends in 2009', Global Investments Trend Monitor, no, 2, 19 January 2010.

World Bank (1999) Global Economic Prospects 1998/1999 Beyond Financial Crisis. Washington D.C.

Word count: 6,185 (9 June 2010) 